\title{
THE SHIM AND PROFESSIONAL MOBILITY ON THE EDUCATIONAL MARKET IN ROMANIA
}

\author{
Ph.D.Professor Dima Ioan Constantin ${ }^{1}$ \\ Valahia University of Târgovişte \\ Teaching assistant, Ph.D. candidate MIHÄESCU Diana Maria ${ }^{2}$ \\ "Lucian Blaga" University of Sibiu
}

\begin{abstract}
The education, the shim and professional mobility interfere in various ways: a high level of education increase the person's shim on the labour market and increases the professional mobility chances; the organization which invest in the employee's training are characterize by a high level of technology, and they focus the investments toward the young employees with a high level of training and they help the professional mobility.
\end{abstract}

The different situations which characterize the instable economic environment, as the one we can find in Romania, it makes very the evaluation from the quality and quantity, shim and professional mobility point of view. The type of professional activity development, the type of contract, the necessary period for the professional shim and balance between the work place and the individual's training level are few of the criteria which help to evaluate the shim and professional mobility.

For this study were used data from The Public Opinion's Barometer (may, 2006) contains data about employment structure in Romania changes made at this level, the relation between the population's level of education and employment.

The results of the study made in Romania in 2006 and the aspect of employment structure, the changes at this level, the relation between population's level of training and employment are represented in the Table no 1.

In general we can see that on the Romanian labour market it's a direct relation between the level of education reached by a person and employment.

The persons who have an intellectual employment or management jobs are graduates of short or long term higher education $(78,5 \%$ and $30,4 \%)$ while technicians or foremen have at least postgraduate high school education $(70,7 \%)$. The high school graduates prepare themselves for an administrative job $(51,1 \%)$, army $(50 \%)$, services and commerce $(51,3 \%)$. Qualified workers $(46,1 \%)$ and unqualified $(40,6 \%)$ are graduates of professional education or apprentice and few of them graduates of the 10 years compulsory education. The persons without education or the one who graduated only the primary school and/or the gymnasium - either are agricultures $(5,2 \%$ and $56,6 \%)$, or work by day in agriculture $(5,9 \%$ and $45,1 \%)$ or stay at home $(4,6 \%$ and $45,4 \%)$.

The results of the study show that it at the society's level, the economic change has made big changes in the employment at the individual level we can see that an important factor is the reached educational level. (Table no 2).

\footnotetext{
${ }^{1}$ dima.ioan_constantin@yahoo.com

2 diana.mihaescu@yahoo.com
} 
Table no 1 .

The relationship between the level of education and employment

\begin{tabular}{|c|c|c|c|c|c|c|}
\hline Employment in 2006 & $\begin{array}{c}\text { Without } \\
\text { school }\end{array}$ & $\begin{array}{c}\text { Primary } \\
\text { School } \\
\text { (I-VIII) }\end{array}$ & $\begin{array}{c}\text { Professional School } \\
\text { (first level, } \\
\text { Professional School } \\
\text { complementary or } \\
\text { apprentice) }\end{array}$ & $\begin{array}{c}\text { High } \\
\text { school }\end{array}$ & $\begin{array}{c}\text { Post- } \\
\text { high } \\
\text { school }\end{array}$ & University \\
\hline Managers, owners. & - & 6,5 & 23,9 & 21,7 & 17,4 & 30,4 \\
\hline Intellectual employments & - & - & 2,0 & 13,3 & 6,1 & 78,5 \\
\hline Technicians or foremen & - & - & 2,4 & 19,5 & 70,7 & 7,3 \\
\hline Administrative workers & - & 8,9 & 4,4 & 51,1 & 20,0 & 15,6 \\
\hline $\begin{array}{c}\text { Employee in services } \\
\text { field and commerce }\end{array}$ & - & 6,3 & 21,3 & 51,3 & 11,3 & 10,1 \\
\hline Military field & - & - & - & 50,0 & 28,6 & 21,4 \\
\hline Artisans and mechanics & - & 10,5 & 63,2 & 21,1 & 5,3 & \\
\hline $\begin{array}{c}\text { Qualified agriculture or } \\
\text { in its own household }\end{array}$ & 5,2 & 56,6 & 26,9 & 6,1 & 4,3 & 0,9 \\
\hline Unemployed & - & 14,6 & 37,7 & 33,3 & 7,7 & 6,9 \\
\hline House wife & 4,6 & 45,4 & 30,8 & 15,4 & 2,9 & 1,0 \\
\hline day -laborer in & 5,9 & 45,1 & 43,1 & 2,0 & 3,9 & - \\
\hline agriculture & - & 11,5 & 46,1 & 36,1 & 5,6 & 0,8 \\
\hline Qualified workers & - & 25,0 & 40,6 & 25,0 & 6,3 & 1,6 \\
\hline Unqualified workers & 1,6 & 16,8 & 10,8 & 8,6 & 6,7 \\
\hline Retired & 3,6 & 53,5 & 19,1 & 31,0 & 14,3 & 16,6 \\
\hline Others & - & 19,1 & 6,0 & 55,3 & - & - \\
\hline Pupils/ Students & - & 33,3 & & &
\end{tabular}

Source: The Public Opinion's Barometer (may, 2006)

The main changes in the employment structure are: a high number of retired people (from $11,7 \%$ in 1990 to $31,6 \%$ in 2005) either because of the age or as a way to avoid the unemployment at a certain age, and the number of unemployed people (from 1,1\% in 1990 to 5,6\% in 2006).

The data from the study allow us to analyse the population's professional path, thus we can identify from which employment category come the biggest number of retired or unemployed people in 2006.

So we can see (Table no 2) that the people's majority, qualified or unqualified workers in 1990, are in 2006 either unemployed or retired. This employment category is with the lowest level of education - outmost vocational or apprentice education.

Another very important aspect is that many persons who were unemployed or day labourer in 2006 in 1990 were taking part into an educational program. The fact that in 2006 they were unemployed can be explained either by a low educational level or by the fact that the skills acquired during the study period didn't match any more with the labour market's demands from Romania. Taking into account that the period from the graduation of the last school and the moment of the survey (may, 2006) is not very big we can say that Romanian labour market became very difficult to be accessed by the persons with a low level of education and for the young people too. In the case of this employment and age categories the professional mobility chances are limited too. 
The relation between the employment rate in 1990 and the one from 2006

\begin{tabular}{|c|c|c|c|c|c|c|c|c|c|c|c|c|c|c|c|c|}
\hline \multirow{3}{*}{ 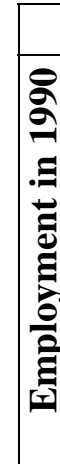 } & \multicolumn{16}{|c|}{ Employment in 2006} \\
\hline & : & 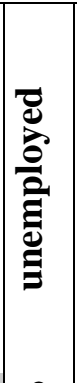 & 离 & 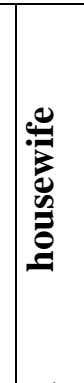 & 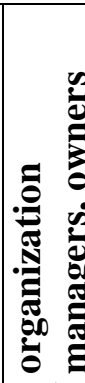 & 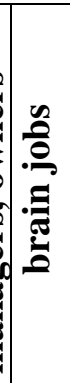 & 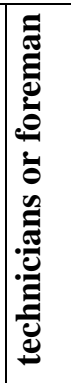 & 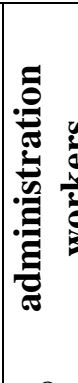 & 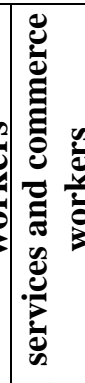 & 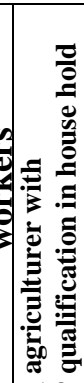 & 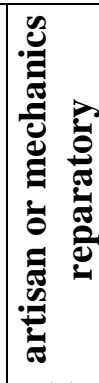 & 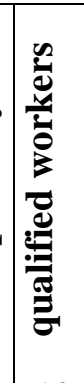 & 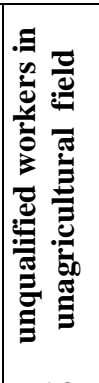 & 齐 & 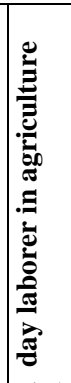 & 惑 \\
\hline & 1 & 2 & 3 & 4 & 5 & 6 & 7 & 8 & 9 & 10 & 11 & 12 & 13 & 14 & 15 & 16 \\
\hline 1. & 30,4 & - & - & - & 0,3 & - & - & - & - & 1,7 & - & - & - & - & - & - \\
\hline 2. & 0,6 & 5,1 & - & - & 1,3 & - & - & - & 1,3 & 1,7 & - & 1,6 & 3,1 & - & 2,0 & \\
\hline 3. & 0,5 & 38,5 & 80, & 921,7 & 19,6 & 26,5 & 7,3 & 20,0 & 38,3 & 16,5 & 21,1 & 23,4 & 42,2 & 35,7 & 29,4 & 38,1 \\
\hline 4. & 4,8 & 1,7 & - & 47,4 & - & - & - & 2,2 & 5,0 & - & - & 2,4 & 4,7 & - & 5,9 & 4,8 \\
\hline 5. & 0,6 & & - & 0,3 & 13,0 & 1,0 & - & - & 1,3 & - & - & - & - & - & - & - \\
\hline 6. & 4,4 & 0,9 & - & 13 & 1 & 63,2 & 4,9 & 4,4 & 2,5 & 0,9 & - & 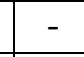 & - & - & - & 7,1 \\
\hline 7. & 4,1 & 5,1 & - & 10,9 & - & 3,1 & 68,3 & 4,4 & 5,0 & 0,9 & - & 0,8 & 1,6 & - & - & 2,4 \\
\hline 8. & 4,2 & 1,7 & - & 4,3 & 1,0 & 2,0 & 2,4 & 40,4 & 1,3 & - & - & - & 1,6 & - & - & - \\
\hline 9. & 4,2 & 2,6 & - & 6,5 & 2,9 & - & 2,4 & 6,7 & 39,0 & 0,9 & - & 0,8 & 1,6 & - & 3,9 & 2,4 \\
\hline 10. & 5,4 & - & - & 2,2 & 2,9 & - & - & 6,7 & 1,3 & 59,1 & - & - & - & - & 7,8 & - \\
\hline 11. & 2,3 & 3,4 & - & - & 0,3 & - & - & 2,2 & - & 0,9 & 57,9 & 0,4 & 1,6 & - & 3,9 & - \\
\hline 12. & 20,3 & 20,5 & - & 19,6 & 12,4 & 1,0 & 12,2 & 8,9 & 6,3 & 10,4 & 10,5 & 64,3 & 20,3 & 14,3 & 7,8 & 19,0 \\
\hline 13. & 5,6 & 5,1 & - & 2,2 & 5,6 & - & - & 4,4 & 1,3 & 2,6 & 10,5 & 2,0 & 21,9 & - & 3,9 & - \\
\hline 14. & 3,5 & - & - & - & - & - & - & - & - & - & - & 0,4 & - & 35,7 & - & - \\
\hline 15. & 0,8 & 1,7 & - & - & 1,6 & - & - & - & - & 0,9 & - & 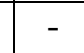 & - & - & 27,5 & - \\
\hline 16. & 0,8 & 2,6 & - & 4,3 & 1,3 & 2,4 & 2,4 & - & - & - & - & 0,8 & - & 7,1 & 2 & 23,8 \\
\hline
\end{tabular}

Source: The Public Opinion's Barometer (may, 2006)

The other employment categories the variations at the structure's employment level during the period 1990- 2006 are insignificant, which means that the professional mobility in Romania is very limited, compared with the educational one.

The older population's professional shim on the labour market became in the last decade in Romania a very difficult process, needing a longer period of time from the moment of graduation or from the moment of loosing the job and until the finding another job.

In 2006, 37\% from the unemployed were graduates of higher education, high school, vocational schools or gymnasium looking for a job. The modulus The transition from school to work, in the Investigation over the labour force in the house management (AMIGO, III-rd semester, 2006) show us the level of education and the necessary period of time for a person who left the educational system for finding a good job) Table no 3). 
Table no 3.

The educational structure of the persons who found a good job, having in view the education level and the necessary period of time for finding it.

\begin{tabular}{|c|c|c|c|c|c|c|c|c|c|}
\hline & \multirow[b]{2}{*}{ Total } & \multicolumn{8}{|c|}{ THE LEVEL OF EDUCATION } \\
\hline & & \begin{tabular}{|l|} 
long \\
term \\
univ.
\end{tabular} & colleges & \begin{tabular}{|c|} 
after \\
highschool \\
education, \\
technical,
\end{tabular} & $\begin{array}{l}\text { high } \\
\text { school }\end{array}$ & vocational & gymnasium & primary & \begin{tabular}{|c|} 
no \\
school
\end{tabular} \\
\hline $\begin{array}{c}\text { Under } \\
3 \\
\text { month }\end{array}$ & 50,0 & 64,9 & 70,5 & 71,9 & 42,7 & 48,5 & 46,1 & * & $*$ \\
\hline $\begin{array}{c}3-5 \\
\text { month }\end{array}$ & 0,9 & 1,5 & $*$ & 3,7 & 0,5 & $*$ & $*$ & - & - \\
\hline $\begin{array}{c}6-8 \\
\text { month }\end{array}$ & 6,6 & 8,1 & 8,4 & 8,5 & 6,6 & 6,9 & 4,1 & - & - \\
\hline $\begin{array}{c}9-11 \\
\text { month }\end{array}$ & 5,7 & 5,5 & - & - & 7,1 & 4,7 & 5,9 & - & - \\
\hline $\begin{array}{l}12-17 \\
\text { month }\end{array}$ & 8,6 & 9,7 & $*$ & 4,3 & 10,8 & 7,6 & 6,1 & - & - \\
\hline $\begin{array}{l}18-23 \\
\text { month }\end{array}$ & 5,2 & 3,7 & $*$ & 5,0 & 7,3 & 3,4 & 4,3 & - & - \\
\hline $\begin{array}{c}24 \\
\text { month } \\
\text { and } \\
\text { over }\end{array}$ & 23,0 & 6,6 & 9,9 & 5,2 & 25,0 & 28,9 & 32,3 & 76,0 & 85,0 \\
\hline
\end{tabular}

Source: Investigation over the labour force in the house management AMIGO, 2006

The most alarming youth segment are the one with no education or only with primary education, with $85 \%$ and $75 \%$ ration they need over 24 month for finding a job, compared with $6,6 \%$ the university graduates.

The high rate of youth unemployment, compared with other age groups as well as the fact that the necessary period for finding a job it is lower related to the higher level of education, therefore the diploma becomes more important at the beginning of the career than on the way. But having a diploma, even of higher education, it doesn't guarantee a place of work it only increases the chances of finding one.

The low number of working places, the competition grow for the one which are left determine, beside the unemployment another phenomena - de classification or the invisible under occupation. Even if this phenomena it is visible on the labor market in Romania, it is obvious that in an prolonged economical crisis it is preferable to be hired on a job under the educational level reached better than to be unemployed. On the group age the phenomena is emphasized among the young people: $12,5 \%$ persons who develop an activity lower than their level of education - age group 15-24 years old and 6,4\% - age group 50- 64 years old. On the employment category the most affected are the operator from the services fields, commerce and the assimilated one, agriculture and qualified agriculture workers, forestry and fishing. For the young people an increase in number of work places adequate to the level of education to drag the professional mobility chances, either inside the organization where they develop an activity (intern mobility) or outside of the organization (extern mobility).

Not all the graduates are debutante on the labor market. A survey show that the students develop an professional activity during their study (48,8\% of students, $16,7 \%$ were working). The 
persons who acquire professional skills during the study period have a higher chance of professional mobility.

The prevailed professional mobility is either the intern or extern one, horizontal or upright, depends on the type of investor. When the investments are made by the individual the extern mobility is higher and when the firm or the institution is the one who invest the intern mobility is higher. At the moment we have a limited number of firms which invest in the employees professional training.

The main characteristics of the firms and of the institutions from Romania which invest in the employees professional training are: high economic power, high level of technology, a high level of competition on the market. In this organization the employee benefits by a organized professional training process with a high standard of quality. These organizations are placed in big towns or in the economic developed areas, ease the intern professional mobility, either horizontal or upright and the personnel has at least a medium level of education and it is mostly young.

For the other professional category and age groups, ANOFM, through its branches which manages active programs for the labor market should be a solution for the shim and professional mobility. At the Agency's level only 2,5\% from the budget is given for developing the active programs the biggest part it is given for paying the unemployment benefit.

The law system, the management attitude opposite to education and professional training of the older population, the economic situation generates the fact that at least at present and on the short term, the number of graduates of higher education it is higher doesn't favor the investments for training the population. Therefore the one who are excluded from the labor market or who doesn't develop an activity in an organization which invest in training have limited chances of professional integration or finding a job adequate to the reached educational level.

Because of the intense changes on the labor market and training for the socio- economic integration through the educational system needs time it is compulsory an detailed analysis over the relation between education, shim and professional mobility, educational offer, the evolution of the labor market.

Based on this studies it is possible to remove any form of school and professional training who are not appropriate with the demands and of prospect for our society, to grow the value of education on the labor market and its contribution to the national level.

To realize a good balance between the professional shim and professional mobility having in view the integration of Romania in the European Union could be analyzed the next few actions developed by the executive power in Romania:

$>$ Romania takes part into different programs of cooperation and bilateral and multi-lateral initiatives in the field of education and professional training - developed on the base of the international agreements in the field and Romanian legislation. This programs and initiatives promote the good practices exchange, balances the education, joint management of the politics and strategies in education, curriculum, institutional evaluation and development, teacher's training, etc.;

$>$ In its quality of state member and focused on developing the quality of education, Romania takes part in European Union's action programs of education and professional training. The main purpose of participation in this program is to develop the European dimension in education, encourage the mobility and to ease the direct cooperation between different units and educational institutions. Romania has developed all the necessary institutional structures for the management of this program. Important information about Romania's European cooperation programs Socrates II, Leonardo da Vinci II, Tempus III and Youth for Europe is provided by: The Ministry of Education and Research , Socrates national Agency- Romania; The national Agency for Leonardo da Vinci; 
$>$ Romania is a member of Stability Pact for South Eastern Europe (SEE) and takes part actively to the cooperation programs and initiatives organized in the field of education and professional training in Working Table 1 - Task Force Education and Youth;

$>$ The cooperation regarding the educational politic in the past few years became more visible at the European level, especially after the European council from Lisbon, march 2000. Romania adopted the priorities and the common goals agreed by the European level regarding the professional training and education development. Therefore the stage of educational reform in Romania is harmonized with the Bologna Process, the program of Education and training 2010 and Copenhaga declaration;

$>$ Seeing the development of education's quality as a priority of the educational system, Romania began taking part in the action programs of the European Union in educational field and professional training, for example : TEMPUS- since 1991 (now Romania develops TEMPUS III); Socrates- since 1997 (now Socrates II ); Leonardo da Vinci- since 1997 (now Leonardo da Vinci II); Youth for Europe- since 1997 (now the program Youth).Romania began to take part in this programs and projects of cooperation developed by the European council and signed the agreement about founding European Center for Modern Languages from Graz (ECML);

$>$ In the Stability Agreement, Romania took part by sending representatives: Education for a democratic citizenship and the management of diversity, History and teaching history, Vocational education and professional training and General Education and improving the educational system. In the next period the attention will be focused on the educational institutions and units participations as members in the cooperation networks and projects in the field of education of the Stability Agreement. It will be pursued that the teachers with special professional performances to be signed up as experts for the programs and the Stability Agreement's projects;

$>$ Romania participation into the programs and bilateral initiatives in the field of education and professional training which include agreements and/or collaboration programs and a large number or partner countries around the world - Argentina, Azerbaidjan, Bulgaria, China, Georgia, Hungary, Italy, Kazakhstan, Maroc, Mexico, Moldavia, Peru, Portugal, Qatar, Russia, Slovakia, Slovenia, Turky, Ukrainia, USA, Vietnam etc. Having in view the program and the two countries interest, the bilateral cooperation can contain: joint scholarships- for part study or full license study and for post graduate study, also doctoral degree; education specialists exchange in change of information and study regarding the content and the organization of education in the two countries; the exchange of teachers for different periods of time for teaching and/or research; direct collaboration between different units and schools etc.;

$>$ Romanian participation in the programs and multilateral initiatives which demand Romania's participation in the Regional Cooperation through: Black Sea Organization founded in 1992 when an academic group from Romania had the initiative of founding the Black Sea University's Organization as an non political and non profit organization. The gathered experience by the founder in the period 1991 and 1992 through the development of five European summer courses with the help of Brugges European College helped strengthening the organization's capacity of developing courses of life long learning type. Around the Black Sea University's Organization developed many research departments, like: National center for sustained development (now it is an autonomous institution); Center for the conflict's prevention, Laboratory for informational technology in education- LITE; European Center for Peace and Development (Belgrade, Yugoslavia); Croatian Diplomatic Academy (Zagreb); Mediteranean Academy of Diplomatic Studies (Malta); International Center of Black Sea Studies (Athens, Grecia) etc.; 
D Romanian participation to the initiative of Educational Reform in Europe and South East (ERI SEE). As a result of the European Union extension Task Force Education and Youth/Enhanced Graz Process with the high rank officials from SEE had the initiative of sustaining the education reform from the region, taking into consideration the needs and the specific demands of the states regarding the educational reform as well as the development trends toward the European Space of Education. ERI SEE it is considered to be interface between the applied reforms in education at the national level in SEE and the European trend regarding the development of some common standards in education- according to the program Education and Training 2010, Copenhaga Declaration and the Bologna Process, etc. 
